UDC 336.12

DOI https://doi.org/10.32838/2663-6468/2020.2/16

Kiforenko O.V.

Uman National University of Horticulture

\title{
THE EUROPEAN UNION BUDGET REVENUES: THE PRESENT STATE OF MATTERS AND PROJECTION
}

The European Union is a unique economic and political union between 27 European countries. The purpose of the EU is to make Europe more competitive on the global market. The general budget of the Union is the instrument which sets out and authorises the total amount of revenue and expenditure deemed necessary for the European Union and the European Atomic Energy Community for each year. The budget is established and implemented in compliance with the principles of unity, budgetary accuracy, annuality, equilibrium, unit of account, universality, specification, sound financial management and transparency. The total European Union budget revenues for the period of five years were analyzed and the projection of the said revenues for two more periods of time, that is for two years, was made in the article. The analysis of the total revenues dynamics of the European Union budget was made and the trend line was built using one of the functions available for the stated purpose. The author analyzed the size of the EU budget as percentage of Gross National Income (GNI) of its member-states for four previous budget periods, that is from 1993-1999 to 2014-2020 and made the projection for the next one, that is for 2021-2027. The analysis of the size dynamics of the EU budget as percentage of Gross National Income of its member-states for four previous budget periods mentioned above was made and the trend line of the said dynamics was built using one of the functions available for the stated purpose. Both functions mentioned above were chosen taking into account the $R^{2}$ value. The negotiations on the 2021-2027 European Union budget are still being held. The European Commission proposed that the Union budget will invest EUR 1279 billion in 2021-2027 (1.114\% of EU-27 GNI). But net beneficiary countries wanted more than 1.074\% while the frugal four wanted a maximum of $1 \%$.

Key words: the EU budget, the GNI-based resource, total revenues, budget period, member-states.

Formulation of the problem. The EU is an economic, political and monetary union that unites 27 member-states. The purpose of the EU is to make Europe more competitive on the global market. According to the Rome Treaty, the EU has a common budget, thanks to which the said union has the possibility to invest into big projects, that no one single member-state can allow itself to, improve the competitiveness level of the European Union on the global market in terms of scientific research, IT-technologies development, food safety standards improvement, etc. That's why so much attention is paid at the way and time frame the EU budget is discussed and adopted within. Most of the publications, in which all the matters of the budget mentioned above are researched and discussed, deal with the legal and taxation issues of the European Union main financial plan. That's why the research paper presented the analysis that is extremely topical and up-to-date nowadays.

Analysis of recent research and publications. There are pretty many publications of both Ukrainian and foreign researchers, in which different aspects of the European Union budget are discussed. Among those mentioned, the following European researchers are worth being noticed here M.L. Seguiti, A. Turrini, F. Heinemann, M. Schratzenstaller, A. Matthews, D. Fiott, Å. Gunnarsson, D. Nerudová, E. Mulligan, M. Fink, L.B. Larsen, L. Andor and others. The major part of them can be divided into two parts - the issues connected with the EU Multiannual Financial Framework 2021-2027 and the ones connected with the taxation in the EU. That means, that the presented research of the EU budget revenues as a whole and its GNI ${ }^{1}$-based own resource in particular is very topical and has the potential to be expanded.

Aim of the article. The aims of the article are as follows:

- to analyze the total European Union budget revenues for the period of five years and to make the projection of the said revenues for two more periods of time, that is for two years, meaning - 2019 and 2020;

$\overline{{ }^{1} \mathrm{GNI}-\text { General National Income }}$ 
- to analyze the total revenues dynamics of the European Union budget and build the trend line using one of the functions available for the stated purpose. The function mentioned above will be chosen taking into account the $\mathrm{R}^{2}$ value;

- to analyze the size of the EU budget as percentage of Gross National Income (GNI) of its member-states for four previous budget periods, that is from 1993-1999 to 2014-2020 and to make the projection for the next one, that is for 2021-2027;

- to analyze the size dynamics of the EU budget as percentage of Gross National Income (GNI) of its member-states for four previous budget periods mentioned above and build the trend line using one of the functions available for the stated purpose. The function mentioned above will be chosen taking into account the $\mathrm{R}^{2}$ value.

Presentation of the main research material. The European Union (EU) is a unique economic and political union between 27 European countries. The predecessor of the EU was created in the aftermath of the Second World War. The first steps were to foster economic cooperation: the idea being that countries that trade with one another become economically interdependent and so more likely to avoid conflict. The result was the European Economic Community, created in 1958 with the initial aim of increasing economic cooperation between six countries: Belgium, Germany, France, Italy, Luxembourg and the Netherlands. Since then, 22 more countries joined (and the United Kingdom left the EU in 2020) and a huge single market (also known as the "internal" market) has been created and continues to develop towards its full potential. What began as a purely economic union has evolved into an organisation spanning many different policy areas, from climate, environment and health to external relations and security, justice and migration. A name change from the European Economic Community to the European Union in 1993 reflected this [1].

The general budget of the Union is the instrument which sets out and authorises the total amount of revenue and expenditure deemed necessary for the European Union and the European Atomic Energy Community for each year. The budget is established and implemented in compliance with the principles of unity, budgetary accuracy, annuality, equilibrium, unit of account, universality, specification, sound financial management and transparency [2].

The EU's sources of income include contributions from member countries, import duties on products from outside the EU and fines imposed when businesses fail to comply with EU rules. The EU countries agree on the size of the budget and how it is to be financed several years in advance [3]. The revenues of the EU budget comprise the following resources:

1) "Traditional" own resources, which consist of customs duties, agricultural duties and sugar and isoglucose levies.

2) The VAT²-based own resource, which consists of the transfer of a percentage of the estimated VAT collected by the Member States to the Union.

3) The GNI-based own resource, which consists of a uniform percentage levy on Member States' GNI set in each year's budget procedure, and was created by Council Decision 88/376/EEC.

${ }^{2}$ VAT - Value Added Tax

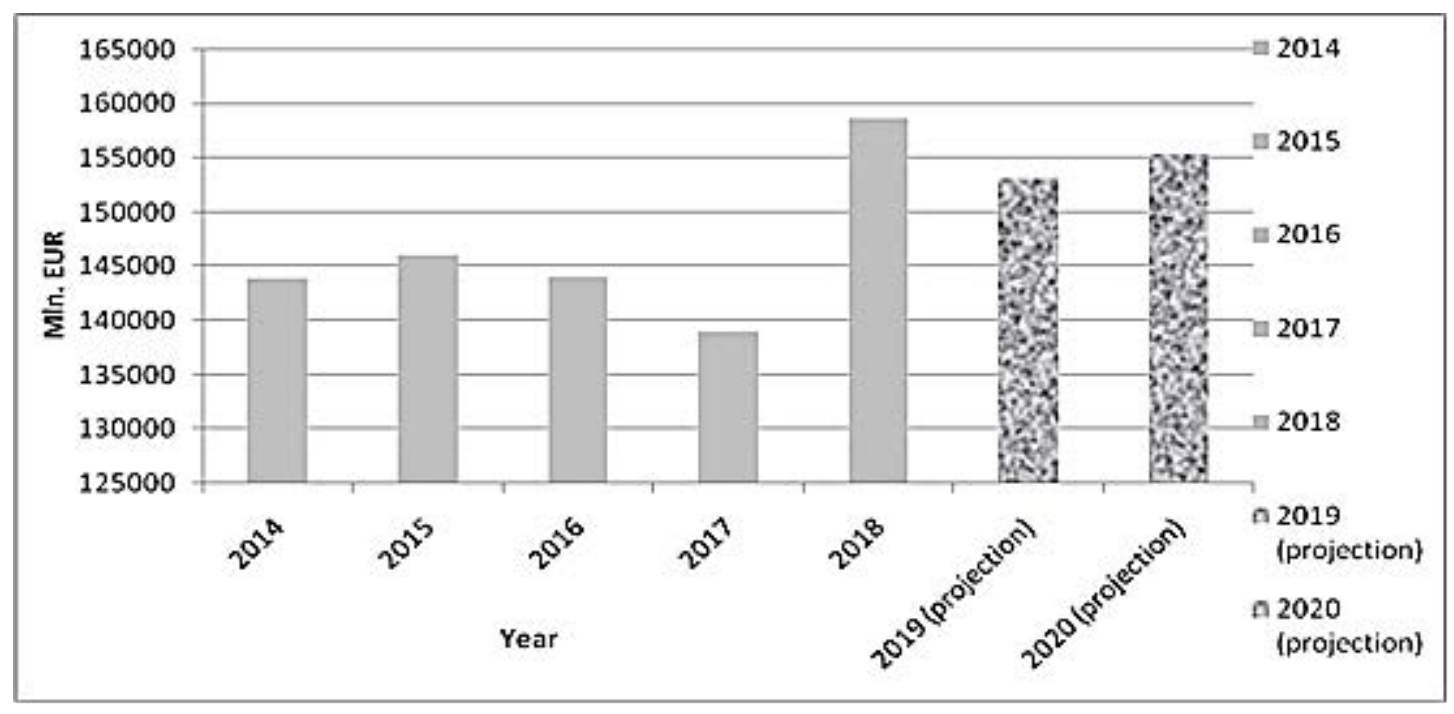

Figure 1. Total Revenues of the European Union Budget with Two Years Projection, mIn EUR 
4) Other revenue and the balance carried over from the previous year, which includes taxes paid by EU staff on their salaries, contributions from non-EU countries to certain EU programmes, and fines paid by companies that are found to be in breach of competition laws or other laws.

5) Correction mechanisms, which correct budgetary imbalances between Member States' contributions is also part of the current own resources system [4].

The EU budget is based on a longer-term plan (the so-called Multiannual Financial Framework (further - MFF). The current long-term EU budget covers 2014-2020 and allows the European Union to invest around EUR 1 trillion over that period [5]. The total revenues of the European Union budget with the projection for two years can be followed in Figure 1.

The data depicted in Figure 1 allow the author make the following conclusions - in 2015 the EU budget revenues increased of $2087.3 \mathrm{mln}$ EUR but in 2016 the said revenues decreased of $1938.2 \mathrm{mln}$ EUR if compared to the previous year. In 2017 the next decrease of $5066 \mathrm{mln}$ EUR can be observed. The situation changed in the following year and we can see the biggest increase in the amount of the total revenues of the EU budget, that is of $19619.4 \mathrm{mln}$ EUR. More than that - in the year 2018 the budget of the European Union had the biggest revenues, that is 158642.6 mln EUR, and the smallest - in 2017, that is $139023.2 \mathrm{mln}$ EUR. Our projection of the amount of total EU budget revenues for the years 2019 and 2020 (under conditions unchanged) is 153064.7 and $155304.8 \mathrm{mln}$ EUR respectively.
The dynamics of the total revenues of the European Union budget can be followed in Figure 2 .

As we see in Figure 2, there is no one clear tendency in the European union budget revenues during the time frame under analysis. An upward tendency can be observed in 2015 followed by the downward one during the next two years, that is in 2016 and 2017. The said downward tendency changed for the opposite once more in 2018, noting the biggest increase in the amount of the EU budget revenues and their biggest amount. The trend line of the European Union budget revenues was made by means of the polynomial function. The said function continues to have an upward trend during the two periods taken for the projection, in this case - for two years. It was this time period that was taken for the projection as the EU long-term budget covers seven years, that is from 2014 to 2020 .

As it was stated above, one of the own resources the EU budget gets its revenues from is the GNIbased own resource. The size of the EU budget as percentage of Gross National Income (GNI) of its member-states can be followed in Figure 3.

Having observed the data in the figure given above, we can state, that the highest percent of the GNI the member-states had to pay into the EU budget was in 1993-1999 MFF and the lowest - in 2014-2020. In the $2000-2006$ the GNI percentage was lower of 0.16 percentage points if compared to the previous time frame. In the time Frame of 2007-2013 the GNI percentage was higer of 0.3 percentage points if compared to the previous time frame stated in Figure 3 . And in 2014-2020 it was once more lower but this

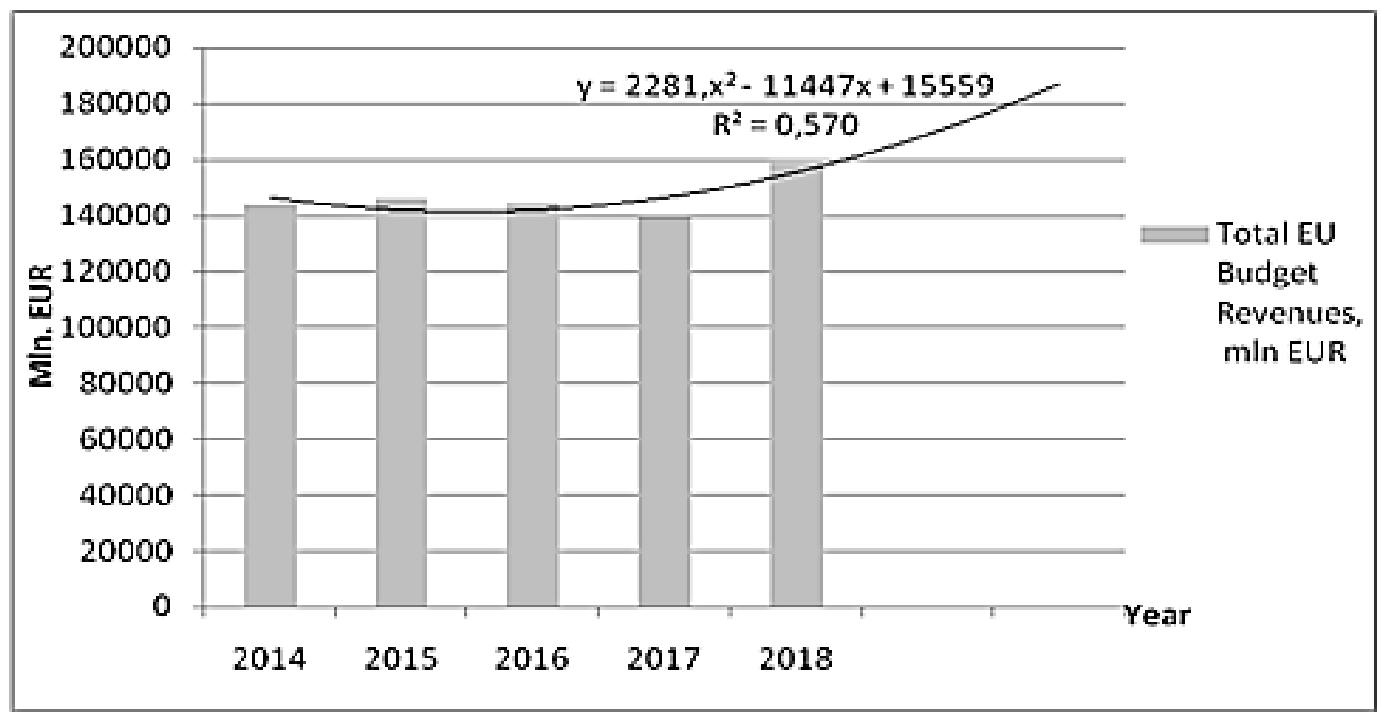

Figure 2. Total Revenues of the European Union Budget, mIn EUR

Source: author's own elaboration on the basis of the data from [6] 
time of 0.12 percentage points. Our projection for the next time frame, that is the next seven years the EU budget should be agreed, meaning - for 2021-2027, is 0.94 percentage points of the GNI of memberstates. In reality, the negotiations on the 20212027 European Union budget are still being held. The Commission proposed that the Union budget will invest EUR 1279 billion in 2021-2027 (1.114\% of EU-27 GNI). The contribution from each Member State will be calculated based on how much the EU will have to pay to the beneficiaries of the EU budget each year, and after deducting revenue from other sources such as customs duties and fines, up to an overall maximum of EUR 1246 billion (or 1.08\% of EU27 GNI) [8].
The dynamics of the size of the EU budget as percentage of Gross National Income (GNI) of its member-states can be followed in Figure 4.

As it can be seen from Figure 4, there is no one clear tendency in the GNI percentage over the time frame under analysis - it is downward in the time frames of 2000-2006 and 2014-2020 but it is upward in 2007-2013 if compared to the previous time frame. The overall trend is downward through the whole time frame under analysis and remains so during one more period of time taken for projection. The trend line was composed with the help of the logarithmic function taking into account the $\mathrm{R}^{2}$ coefficient value. But, the ongoing talks on the member-states contributions into the EU budget show, that, most

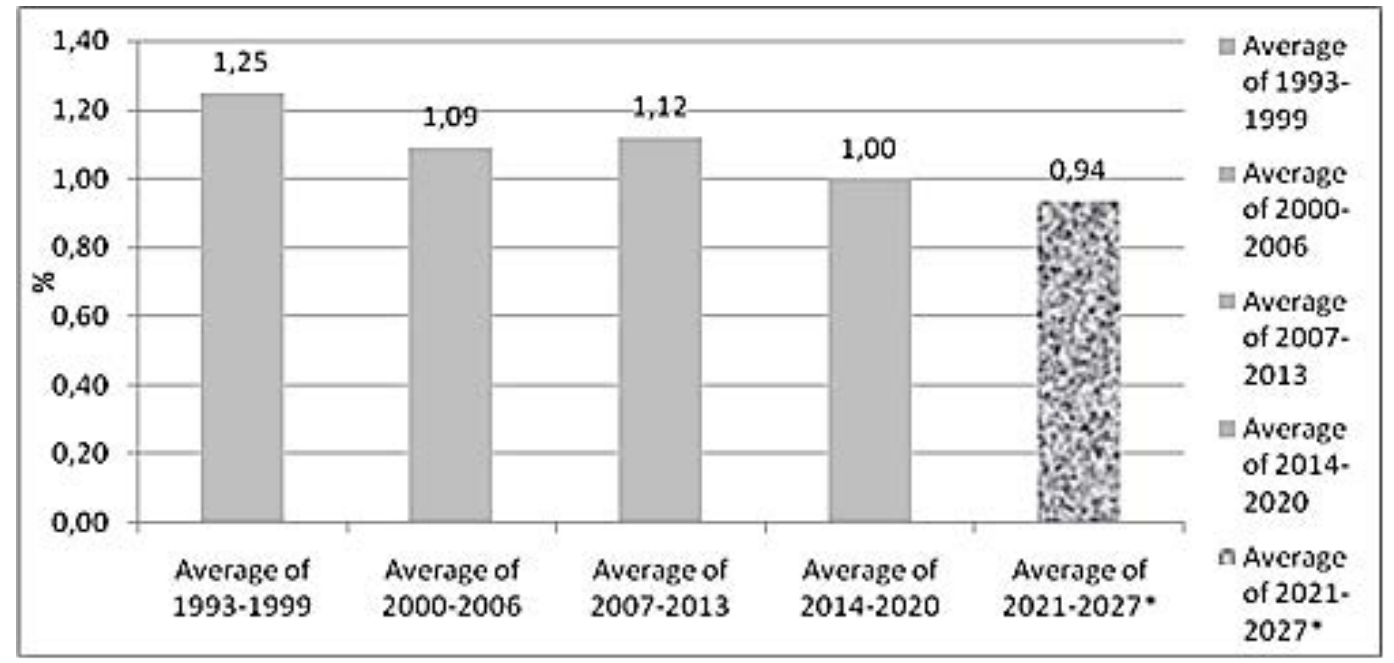

Figure 3. The Size of the EU Budget as Percentage of Gross National Income (GNI) of its Member-States, \%

* Projection

Source: author's own elaboration on the basis of the data from [7]

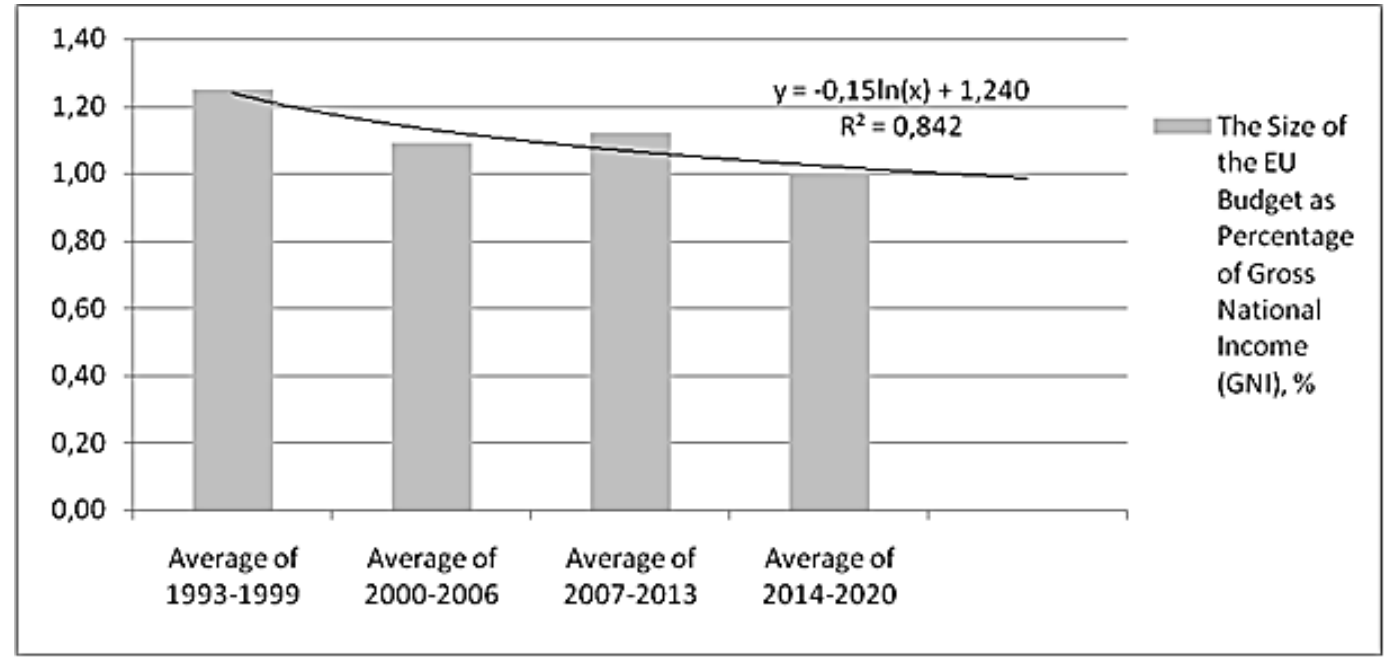

Figure 4. The Dynamics of the Size of the EU Budget as Percentage of Gross National Income (GNI) of its member-states, \%

Source: author's own elaboration on the basis of the data from [7] 
likely, they should be increased. The justification of the European commission is as follows: "Compared across financial frameworks, national contributions increase with inflation and economic growth, just as national budgets do. In contrast to national budgets, however, the EU financial framework spans over 7 years and over the long term, these increases appear more pronounced. When comparing the two financial framework, one needs to consider that combined they capture 14 years of inflation and economic growth. A direct comparison would therefore be distorted. If looking only at the end years of the two frameworks (2020 versus 2027), the national contributions for all Member States combined would go up by a third" [8].

Conclusions. Both the Sibiu Declaration of EU Heads of State or Government and the 2019-2024 Strategic Agenda state that "the EU must give itself the means to match its ambitions, attain its objectives and carry through its policies" [9]. That means that the budget of the European Union has a vital importance for both the EU as a Community and every member-state in particular. Time is running and delays to the future EU budget are costly. Not having an agreement in time would affect students, farmers and researchers, as well as everybody else who benefits from the EU budget. The EU's current longterm budget 2014-2020 was adopted six months too late having negative consequences for many citizens, in our Member States and beyond [10].

The EU's current budget framework runs to the end of this year, so the new one will cover the period from 2021 to 2027. As of the analysis made above, there is no one clear tendency in the European union budget revenues during the time frame under analysis. An upward tendency can be observed in 2015 followed by the downward one during the next two years, that is in 2016 and 2017. The said downward tendency changed for the opposite once more in 2018, noting the biggest increase in the amount of the EU budget revenues and their biggest amount. The trend line of the European Union budget revenues was made by means of the polynomial function. In addition, in the year 2018 the budget of the European Union had the biggest revenues, that is $158642.6 \mathrm{mln}$ EUR, and the smallest in 2017, that is $139023.2 \mathrm{mln}$ EUR. The projection of the amount of the total EU budget revenues for the years 2019 and 2020 (under conditions unchanged) is 153064.7 and $155304.8 \mathrm{mln}$ EUR respectively.
The next analysis point was the size dynamics of the EU budget as percentage of Gross National Income (GNI) of its member-states for four previous budget periods. The highest percent of the GNI the member-states had to pay into the EU budget was in 1993-1999 MFF and the lowest - in 2014-2020. Our projection for the next time frame, that is the next seven years the EU budget should be agreed, meaning - for 2021-2027, is 0.94 percentage points of the GNI of member-states (under the conditions unchanged).

Besides the fact that everybody seems to understand the importance to reach the agreement on the 2021-2027 MFF, according to the European Council Report "Until now, however, the EU Heads of State or Government have not really attempted to reach an agreement. Most recently, in December 2019, the incoming President of the European Council, Charles Michel, was given a mandate to take the negotiations forward with the aim of reaching a final agreement" [9]. What should be paid special attention at, is that Brexit has left a $€ 75 \mathrm{bn}(\$ 81 \mathrm{bn}$; $£ 63 \mathrm{bn}$ ) gap in the seven-year budget. The UK was a net contributor to the EU. The so-called "frugal four" of Denmark, Austria, Sweden and the Netherlands said they would not accept a budget of more than $1 \%$ of the bloc's GDP. Both the frugal four and net beneficiary countries - 17 member states including Spain, Portugal, Greece, Poland and Hungary dubbed the "friends of cohesion" - rejected summit chairman Charles Michel's compromise proposal, which would have capped joint spending at $1.069 \%$ of joint GDP. That was slightly less than his original proposal of $1.074 \%$, equivalent to $€ 1.09$ trillion. But net beneficiary countries wanted more than $1.074 \%$ while the frugal four wanted a maximum of $1 \%$ [11]. After the failure of the two-day European Council dedicated to EU budget talks for the period 2021-2027, the bloc must reconsider its way of functioning and should head for a budgetary federalism. "For sure there will be a new summit in the coming months", says Marta Pilati, policy analyst at the European Policy Center. "It is not clear whether it will be at the regular summit in March or whether it will be an extraordinary summit. They might agree on that occasion but there is a little chance. If they don't then there will be other summits or just one in the coming months towards the second half of the year" [12].

\section{References:}

1. The European Union. What it is and what it does. URL: https://op.europa.eu/webpub/com/eu-what-it-is/en/.

2. Budgets. Official Journal of the European Union. URL: https://eur-lex.europa.eu/legal-content/EN/TXT/ $\mathrm{PDF} /$ ?uri=CELEX:32019B0333\&from=EN. 
3. How the EU is funded. URL: https://europa.eu/european-union/about-eu/eu-budget/revenue-income en? cookies $=$ disabled.

4. The Union's revenue. URL: https://www.europarl.europa.eu/factsheets/en/sheet/27/the-union-s-revenue.

5. European Commission. Integrated Financial Reporting Package. URL: https://ec.europa.eu/budget/library/ biblio/media/2017/2017_IFRP_brochure_web_final.pdf.

6. EU expenditure and revenue $20 \overline{4}-20 \overline{2} 0$. URL: https://ec.europa.eu/budget/graphs/revenue_expediture. html? cookies=disabled.

7. European Commission. URL: https://ec.europa.eu/budget/library/biblio/media/2017/2017_IFRP_brochure_ web final.pdf.

8. EU Budget for the Future. URL: https://ec.europa.eu/info/sites/info/files/factsheet-eu-budget-financing_pdf.

9. The European Council and the 2021-27 Multiannual Financial Framework [Electronic Resource] // Access mode: https://www.europarl.europa.eu/RegData/etudes/BRIE/2020/631732/EPRS_BRI(2020)631732_EN.pdf.

10. EU Budget 2021-2027. URL: https://ec.europa.eu/commission/news/eu-budget-2021-2027-2019-jun-13_en.

11. EU budget: Talks end amid stand-off between "frugal" and other nations. URL: https://www.bbc.com/ news/world-europe-51594002.

12. EU budget: the rule of "deadlock as usual". URL: https://www.thenewfederalist.eu/eu-budget-the-rule-ofdeadlock-as-usual?lang=fr.

\section{КіфореНКо О.В. ДОХОДИ БЮДЖЕТУ ЄВРОПЕЙСЬКОГО СОЮЗУ: СУЧАСНИЙ СТАН ТА ПРОГНОЗ}

Європейський Союз - це унікальний економічний та політичний союз між 27 європейськими країнами. Мета СС - зробити Європу більш конкурентоспроможною на світовому ринку. Загальний бюджет Союзу - ие інструмент, який визначає та затверджує загальну суму доходів та витрат, які вважаються необхідними для Європейського Союзу та Європейського співтовариства з атомної енергії на кожен рік. Бюджет встановлюється та виконується відповідно до принципів єдності, бюджетної точності, щңорічності, рівноваги, єдиної розрахункової одиниці, універсальності, специфікаиії, надійного фінансового менеджменту та прозорості. У статті проаналізовано загальний обсяг доходів бюджету Європейського Союзу за п'ять років та зроблено прогноз вказаних доходів на два наступні часові періоди, тобто на два роки. Було також проаналізовано динаміку загальної суми доходів бюджету Європейського Союзу та побудовано лінію тренду, використовуючи одну з функиій, придатних для зазначеної мети. Автор проаналізував розмір бюджету ЄС у відсотках від валового начіонального доходу (ВНД) його країн-членів за чотири попередні бюджетні періоди, тобто з 1993-1999 по 2014-2020 роки, та зробив прогноз на бюджетний період 2021-2027 років. Проведено аналіз динаміки розмірів бюджету ЄС у відсотках від валового національного доходу його державчленів за чотири попередні бюджетні періоди, зазначені вище, та побудована лінія тренду зазначеної динаміки із використанням однісї з функиій, придатних для зазначеної мети. Обидві функиії, зазначені вище, були обрані відповідно до значення $R^{2}$. Переговори щодо бюджету Свропейського Союзу на 2021-2027 роки ще тривають. Свропейська комісія запропонувала, щоб бюджет Союзу інвестував 1279 млрд євро у 2021-2027 роках (1,114\% ВНД краӥн-членів СС-27). Але країни-бенефіціари хотіли більше ніж 1,074\% ВНД, тоді як ощадлива четвірка воліла щонайбільше 1\% ВНД.

Ключові слова: бюджет ЄС, ВНД-ресурс, загальні доходи, бюджетний період, краӥни-члени. 